\title{
Monitoring Trypanosoma cruzi infection in triatomines using PCR in Mato Grosso do Sul, Brazil
}

\author{
Marlon Cezar Cominetti ${ }^{[1]}$, Robson Ferreira Cavalcante de Almeida ${ }^{[1]}$, Guilmara Maria do \\ Amaral Gonçalves ${ }^{[2]}$ and Renato Andreotti ${ }^{[3]}$
}

[1]. Programa de Pós Graduação em Doenças Infecciosas e Parasitárias, Faculdade de Medicina, Universidade Federal de Mato Grosso do Sul, Campo Grande, MS. [2]. Laboratório Regional de Entomologia, Núcleo Regional de Saúde, Secretaria de Estado de Saúde, Campo Grande, MS. [3]. Sanidade Animal, Empresa Brasileira de Pesquisa Agropecuária Gado de Corte, Campo Grande, MS.

\begin{abstract}
Introduction: The aim of the present study was to assess the polymerase chain reaction (PCR) as a method for detecting Trypanosoma cruzi infection in triatomines that had been previously determined by microscopic examination in the State of Mato Grosso do Sul, Brazil. Methods: In total, 515 specimens were collected. Material from the digestive tract of each triatomine was analyzed for the presence of T. cruzi by microscopic examination and PCR using the 121/122 primer set. Results: Among the 515 specimens tested, $58(11.3 \%)$ were positive by microscopy and $101(19.61 \%)$ were positive by PCR and there was an association between the results of the techniques $\left(\chi^{2}=53.354, \mathrm{p}=0.001\right)$. The main species of triatomine identified was T. sordida $(95.5 \%)$ Conclusions: The use of PCR in entomological surveillance may contribute to a better assessment of the occurrence of $T$. cruzi in triatomine populations.
\end{abstract}

Keywords: Epidemiology. Triatomine infection monitoring. Polymerase chain reaction.

Microscopy examination. Trypanosoma cruzi.

\section{INTRODUCTION}

Trypanosoma cruzi is a protozoan belonging to the order Kinetoplastida and the Trypanosomatidae family. T. cruzi is the causative agent of Chagas disease and is transmitted by triatomines, which are Hemiptera insects of the Reduviidae subfamily that are characterized by hematophagy (both males and females) from juvenile to adult stages ${ }^{1}$.

Among the 138 described species of triatomines, only four play a direct role in the epidemiology of the parasite ${ }^{2}$ : Triatoma brasiliensis (Neiva, 1911), Panstrongylus megistus (Burmeister, 1835), Triatoma pseudomaculata (Corrêa and Espínola, 1964) and Triatoma sordida (Stal, 1859). In a recent study of Triatominae in the State of Mato Grosso Sul (MS), T. sordida was frequently found to be parasitized by flagellate protozoa. ${ }^{3}$ In the same study, the presence of three major species of triatomines was confirmed in MS: T. brasiliensis (Neiva, 1911), P. megistus (Burmeister, 1835) and T. sordida (Stal, 1859). Infestation rates for domiciliary and peridomestic areas

Address to: Dr. Marlon Cezar Cominetti. Lab. Biologia Molecular/Sanidade Animal/EMBRAPA Gado de Corte. Avenida Rádio Maia, Vila Popular, 79106-550 Campo Grande, MS, Brasil.

Phone: 5567 3368-2173

e-mail: mccominetti@gmail.com

Received 5 February 2013

Accepted 12 June 2013 were only significant for Triatoma sordida $(9.3 \%$ and $86.6 \%$, respectively), whereas T. brasiliensis and P. megistus exhibited less than $0.2 \%$ infestation ${ }^{3}$.

T. cruzi in triatomines is identified using optical microscopy and material extracted from the digestive tract of the insect. Although this method is inexpensive and widely used, various drawbacks have been reported, particularly in relation to sensitivity and specificity ${ }^{4,5}$.

The aim of the present study was to evaluate the frequency of infection with T. cruzi in triatomines in the State of Mato Grosso do Sul, Brazil using polymerase chain reaction (PCR) and microscopic examination (ME).

\section{METHODS}

\section{Study area}

Insects were collected in the municipalities of Jaraguari (May to August 2009 and September 2011), Rochedo, Caarapó, Douradina, Antônio João, Dourados, Terenos, São Gabriel do Oeste, Aparecida do Taboado, Paranaíba, Rio Verde de Mato Grosso, Corumbá, Miranda and Aquidauana (August 2011 to November 2012) in the State of Mato Grosso do Sul (Figure 1) using the method described by Cominetti et al.

\section{Triatomine identification and microscopic examination}

Triatomines were identified using the dichotomous keys proposed by Carcavallo et al. Flagellated protozoa were detected using the method described by Souza. 


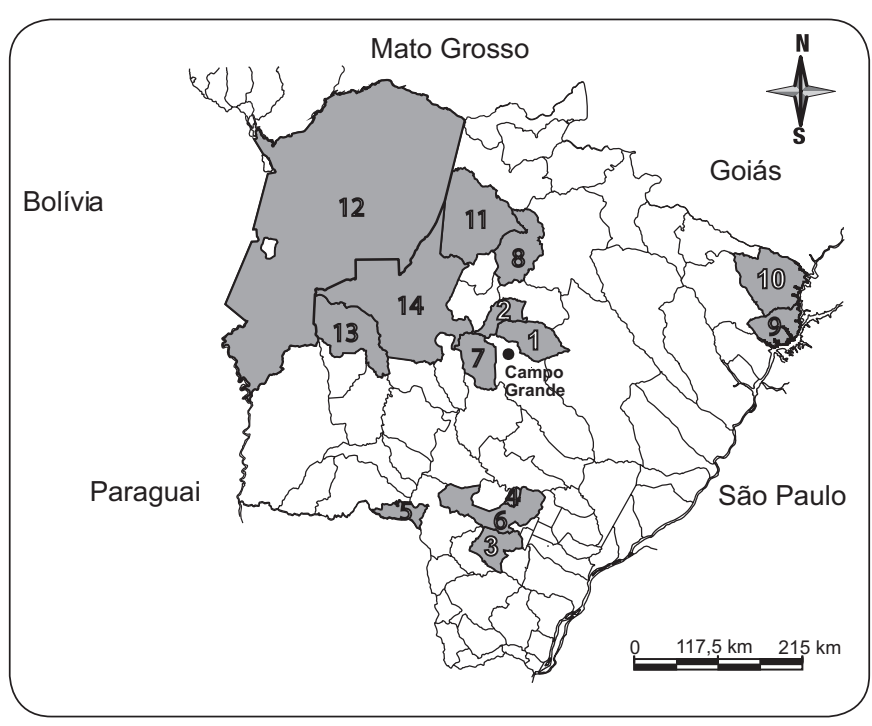

FIGURE 1 - Map of the state of Mato Grosso do Sul, Brazil, highlighting municipalities where insects were captured. 1: Jaraguari; 2: Rochedo; 3: Caarapó; 4: Douradina; 5: Antônio João; 6: Dourados; 7: Terenos; 8: São Gabriel do Oeste; 9: Aparecida do Taboado; 10: Paranaíba; 11: Rio Verde de Mato Grosso; 12: Corumbá; 13: Miranda; 14: Aquidauana.

\section{DNA extraction and PCR}

Genomic deoxyribonucleic acid (DNA) was extracted from the insects as described by Westenberger et al. The integrity of the DNA sample was determined using $0.8 \%$ agarose gel electrophoresis, staining with ethidium bromide $(0.5 \mu \mathrm{g} / \mathrm{ml})$ and visualization under ultraviolet light. Additionally, one glass slide containing material from the digestive tract of the insects was analyzed. After the fixed material was scraped from the slide, DNA extraction was performed as described above.

The following primers described by Wincker et al ${ }^{10}$ were used for molecular identification of T. cruzi: 121 (5'-AAATAATGTACGGG (T/G) GAGATGCATGA-3') and 122 (5'-GGTTCGATTGGGGTTGGTGTAATATA-3'). This set of primers allows the amplification of $330 \mathrm{bp}$ of kDNA from T. $\mathrm{cruzi}^{10}$. The amplification scheme utilized was previously described by Schijman et al. Under natural conditions, T. cruzi and Trypanosoma rangeli frequently co-infect triatomines. Therefore, the samples were also subjected to PCR for T. rangeli using the primers $\operatorname{TrF} 3$ (5'-CCCCATACAAAACACCCTT-3') and TrR8 (5'-TGGAATGACGGTGCGGCGAC-3'), which target a conserved subtelomeric region in T. rangeli $(\mathrm{SubTr}$, GenBank accession number: AF426020). The amplification profile utilized was previously described by Chiurillo et al. All amplification reactions were performed on an Eppendorf AG 22331 thermocycler. Control DNA (T. cruzi as positive and $T$. rangeli as negative) was kindly donated by Dr. Marta M.G. Teixeira (Universidade de São Paulo, Brazil). Furthermore, ultrapure water was used as an additional negative control.

The reactions were performed in a final volume of $25 \mu 1$ containing 1X PCR buffer [10mM Tris- $\mathrm{HCl}(\mathrm{pH} 8.3), 50 \mathrm{mM}$ $\mathrm{KCl}], 1.5 \mathrm{mM} \mathrm{MgCl}, 0.2 \mathrm{mM}$ dNTP mix, $5 \mathrm{pmol}$ of each primer, $1 \mathrm{U}$ of Taq DNA polymerase (Platinum ${ }^{\circledR}$, Invitrogen) and 20ng of genomic DNA.
The amplification products were visualized under ultraviolet light after electrophoresis on an agarose gel (2\%) and staining with ethidium bromide.

\section{Statistical analysis}

The results were compared using the chi-squared test $\left(\chi^{2}\right)$ with a significance level of $5 \%$. Statistical analysis was performed using MedCalc 12.4.0.0.

\section{RESULTS}

In total, 515 samples were analyzed. Among the samples, 58 $(11.3 \%)$ were positive for flagellated protozoa as determined by optical microscopy, and 101 (19.6\%) were positive for T. cruzi as determined by PCR.

The main species of triatomine identified was T. sordida, which represented approximately $95.5 \%$ of the specimens collected, thus confirming the findings of Almeida et al. The frequency of $T$. cruzi infection in this species was $10.7 \%$ when assessed by microscopy and $18.1 \%$ when assessed by PCR.

Association was found between the results obtained by the techniques $\left(\chi^{2}=53.354, p=0.001\right)$ (Table 1) and the number of positive samples by PCR was higher than by ME.

PCR was the only technique that has found $T$. cruzi in triatomines in the municipalities of Rochedo, Corumbá, Aquidauana and Terenos (Table 2), since ME only confirms the cases in which the parasite is visible in the test, and the PCR also identifies the parasite in samples where this was not seen.

Reactions using primers for $T$. rangeli (data not shown) produced no overlapping data, thereby confirming that the amplicons were specific to $T$. cruzi.

TABLE 1 - Comparison of the results obtained by PCR and microscopy in triatomines from the municipalities of Mato Grosso do Sul, Brazil.

\begin{tabular}{lccc}
\hline & \multicolumn{3}{c}{ PCR } \\
\cline { 2 - 4 } ME & positive & negative & total \\
\hline Positive & 58 & 0 & 58 \\
Negative & 43 & 414 & 457 \\
\hline Total & 101 & 414 & 515 \\
\hline
\end{tabular}

ME: microscopic examination; PCR: polymerase chain reaction.

\section{DIsCUsSION}

In Brazil, measures to control triatomine populations are enacted after the detection of insect outbreaks ${ }^{2}$ and involve the use of insecticides in the infested areas. This practice has been effective for many years ${ }^{13,14}$. Microscopic examination of material from the digestive tract of the insects is routinely performed to monitor the distribution of flagellate protozoa (possibly $T$. cruzi). However, microscopy does not permit 
TABLE 2 - Triatomines positive for T. cruzi by PCR and microscopy in municipalities of the State of Mato Grosso do Sul, Brazil.

\begin{tabular}{|c|c|c|c|c|}
\hline \multirow[b]{2}{*}{ City } & \multirow[b]{2}{*}{ Species } & \multicolumn{3}{|c|}{ Positive } \\
\hline & & $\mathrm{n}^{*}$ & $\mathrm{ME}$ & PCR \\
\hline Jaraguari & T. sordida & 260 & 45 & 76 \\
\hline Rochedo & T. sordida & 64 & - & 3 \\
\hline \multirow[t]{2}{*}{ Caarapó } & P. megistus & 1 & 1 & 1 \\
\hline & P. geniculatus & 4 & - & 1 \\
\hline Douradina & T. sordida & 1 & - & - \\
\hline Miranda & T. sordida & 7 & - & - \\
\hline Terenos & T. sordida & 48 & - & 1 \\
\hline Rio Verde de Mato Grosso & T. sordida & 17 & - & - \\
\hline Aparecida do Taboado & T. sordida & 54 & 10 & 10 \\
\hline São Gabriel do Oeste & T. matogrossensis & 8 & - & - \\
\hline Paranaíba & T. sordida & 22 & - & - \\
\hline Dourados & P. megistus & 1 & $* *$ & 1 \\
\hline Antônio João & T. sordida & 1 & - & - \\
\hline \multirow[t]{3}{*}{ Aquidauana } & T. matogrossensis & 9 & 2 & 5 \\
\hline & T. sordida & 12 & - & 2 \\
\hline & Rhodnius sp. & 1 & - & - \\
\hline Carumbá & T. sordida & 5 & - & 1 \\
\hline Total & & 515 & 58 & 101 \\
\hline
\end{tabular}

*number of triatomines captured; ** inconclusive; ME: microscopic examination; PCR: polymerase chain reaction; P: Panstrongylus; T: Triatoma.

the accurate identification of $T$. cruzi because other species of trypanosomes are morphologically indistinguishable from T. cruzi, thereby generating false-positive results. Furthermore, microscopy does not detect the presence of the flagellates in triatomine as PCR, evidenced in the present study.

Advantages of PCR over ME with respect to sensitivity have been reported for T. cruzi ${ }^{4}$, Acanthamoeba spp. ${ }^{15}$, Plasmodium spp. ${ }^{16}$, Babesia spp. ${ }^{17}$, Trypanosoma evansi ${ }^{18}$ and Leishmania spp. ${ }^{19}$. Advantages related to specificity have also been reported ${ }^{20}$. Furthermore, PCR is more efficient than ME for the detection of T. cruzi in Triatoma infestans feeding on patients with Chagas diseases, with a difference of $46 \%$ between PCR and $\mathrm{ME}^{20}$. Previous studies have reported differences of $34.9 \%$ (Rhodnius prolixus), $14.5 \%$ (Triatoma dimidiata) ${ }^{21}$ and $24.6 \%$ $(T \text {. infestans })^{5}$ between PCR and ME. In the present study, the difference between the techniques (with respect to the frequency of positive results) was $8.4 \%$. Although this value is lower than that of previous studies, PCR still exhibited highest number of triatomines infected by $T$. cruzi than ME.

A combination of PCR and optical microscopy to monitor T. cruzi in triatomines may ensure better results in terms of the presence of the parasite, as shown by the results in the municipalities of Rochedo, Dourados, Corumbá, Aquidauana and Terenos. However, considering the true sensitivity and specificity of microscopic examination, questions may arise regarding the current distribution of flagellated protozoa among triatomines, e.g., what is the true distribution of the parasite among triatomines?

In the present study, the proportion of false-negative results in microscopic examination was approximately $8.2 \%$. Considering this issue and taking the data published by Almeida et al. regarding the frequency of triatomines positive for T. cruzi by ME in the State of Mato Grosso do Sul as an example, the number of insects positive for the parasite should be 724 $(8.2 \%)$ rather than $15(0.2 \%)$ found by Almeida et al. Similar or higher values have been reported in other studies comparing these techniques ${ }^{4,5,20,21}$, which demonstrates that the PCR results may be different from the results reported by the current official surveys. Additionally, results obtained from first- and secondstage nymphs using ME are underestimated because of the difficulty in obtaining feces during these stages. This difficulty does not exist when PCR is performed ${ }^{5}$.

In the municipality of Dourados, ME was performed using fixed material on a microscope slide that was previously classified as inconclusive for T. cruzi. Inconclusive results in ME may be caused by parasite deformation during preparation on the microscope slide, which hinders the identification of the protozoan. In the present study, the identity of the flagellated protozoa found by microscopy was confirmed by PCR, which demonstrates the effectiveness of this tool, particularly with respect to controversial points that may arise during the identification process. Other studies have shown that PCR may detect the DNA of parasites on microscope slides even years after preparation ${ }^{22,23}$.

False-positive results are a potential problem with PCR when used for identification of $T$. $\mathrm{cruzi}^{24}$. To reduce the possibility of false-positive results, a negative control was used in the present study. In addition, the different steps of the technique were performed in different rooms.

Although the epidemiological importance of ME is clear in terms of disease control, the use of sensitive techniques, such as PCR, can increase the accuracy of the epidemiological investigation and enable the optimal allocation of financial resources. Furthermore, PCR may be used in epidemiological surveys of other agents of public health importance without significant additional implementation costs.

The frequency of capture of $T$. sordida was higher than that of the other triatomines, which confirms the results of previous entomological surveys in which this species was frequently found ${ }^{3,14,25,26}$. Although previous studies have reported a low rate of $T$. cruzi infection ${ }^{2,3,25}$, the present study suggests that these values may be underestimated and that PCR is essential as a tool for detection in official surveys.

Clearly, one detection technique does not exclude the other. The utilization of ME and PCR in combination contributes greater efficacy in identifying outbreaks of the parasite and also a more accurate mapping of its distribution.

\section{CONFLICT OF INTEREST}

The authors declare that there is no conflict of interest. 


\section{ACKNOWLEDGMENTS}

The authors wish to thank the Laboratório Regional de Entomologia, Núcleo Regional de Saúde, Secretaria de Estado de Saúde for their assistance and Dr. Marta M.G. Teixeira (Universidade de São Paulo, Brazil) for the generous gift of $T$. cruzi and $T$. rangeli genomic DNA.

\section{FINANCIAL SUPPORT}

Embrapa Gado de Corte, Conselho Nacional de Desenvolvimento Científico e Tecnológico (CNPQ) and Fundação de Apoio ao Desenvolvimento do Ensino, Ciência e Tecnologia do Estado de Mato Grosso do Sul (Fundect-MS). PhD scholarship provided by Coordenação de Aperfeiçoamento de Pessoal de Nivel Superior (CAPES).

\section{REFERENCES}

1. Rey L. Parasitologia: parasitos e doenças parasitárias do homem nos trópicos, $4^{\text {th }}$ ed. Rio de Janeiro: Guanabara Koogan; 2008.

2. Ministério da Saúde, Secretaria de Vigilância em Saúde, Departamento de Vigilância Epidemiológica. Guia de vigilância epidemiológica, $7^{\text {th }}$ ed. Brasília: Ministério da Saúde; 2009.

3. Almeida PS, Ceretti Júnior W, Obara MT, Santos HR, Barata JM. Survey of Triatominae (Hemiptera: Reduviidae) fauna in domestic environments and natural infection by Trypanosomatidae in the State of Mato Grosso do Sul. Rev Soc Bras Med Trop 2008; 41:374-380.

4. Braz LMA, Raiz R, Amato Neto V, Alárcon RS, Gakyia E, Okay TS. The detection of Trypanosoma cruzi in Triatoma infestans: comparison of a PCR-based assay with microscopical examination. Ann Trop Med Parasitol 2007; 101:461-465.

5. Pizarro JC, Lucero DE, Stevens L. PCR reveals significantly higher rates of Trypanosoma cruzi infection than microscopy in the Chagas vector, Triatoma infestans: high rates found in Chuquisaca, Bolivia. BMC Infect Dis $2007 ; 27: 66$.

6. Cominetti MC, Andreotti R, Oshiro ET, Dorval ME. Epidemiological factors related to the transmission risk of Trypanosoma cruzi in a Quilombola community, State of Mato Grosso do Sul, Brazil. Rev Soc Bras Med Trop 2011; 44:576-581.

7. Carcavallo RU, Rodrigues MEF, Galvão C, Rocha DS, Girón IG, Arocha MAO, et al. Habitats e fauna relacionada. In: Carcavallo RU, Girón IG, Jurberg J, Lent H, editors. Atlas dos vetores da doença de Chagas nas Américas. Rio de Janeiro: Fundação Oswaldo Cruz; 1997. p. 107-244.

8. Souza MA. Morphobiological characterization of Trypanosoma cruzi Chagas, 1909 and its distinction from other trypanosomes. Mem Inst Oswaldo Cruz 1999; 94:205-210.

9. Westenberger SJ, Sturm NR, Yanega D, Podlipaev SA, Zeledón R, Campbell DA, et al. Trypanosomatid biodiversity in Costa Rica: genotyping of parasites from Heteroptera using the spliced leader RNA gene. Parasitology 2004; 129:537-547.

10. Wincker P, Britto C, Pereira JB, Cardoso MA, Oelemann W, Morel $\mathrm{CM}$. Use of a simplified polymerase chain reaction procedure to detect
Trypanosoma cruzi in blood samples patients in a rural endemic area. Am J Trop Med Hyg 1994; 51:771-777.

11. Schijman AG, Bisio M, Orellana L, Sued M, Duffy T, Jaramillo AMM, et al. International study to evaluate PCR methods for detection of Trypanosoma cruzi DNA in blood samples from Chagas disease patients. PLoS Negl Trop Dis 2011; 5:e931.

12. Chiurillo MA, Crisante G, Rojas A, Peralta A, Dias M, Guevara P, et al. Detection of Trypanosoma cruzi and Trypanosoma rangeli infection by duplex PCR assay based on telomeric sequences. Clin Diagn Lab Immunol 2003; 10:775-779.

13. Silveira AC. Current situation with Chagas disease vector control in the Americas. Cad Saude Publica 2000; 16:35-42.

14. Peñaranda-Carrillo R, Moreira EF, Silveira AC, Leite J, Vinhaes MC, Castro C, et al. Evaluation of the impact of vector control programs through serological testing in Mambaí/Buritinópolis, Goiás State. Rev Soc Bras Med Trop 2002; 35:331-338.

15. Yera H, Zamfir O, Bourcier T, Ancelle T, Batellier L, Dupouy-Camet $\mathrm{J}$, et al. Comparison of PCR, microscopic examination and culture for the early diagnosis and characterization of Acanthamoeba isolates from ocular infections. Eur J Clin Microbiol Infect Dis 2006; 26:221-224

16. Johnston SP, Pieniazek NJ, Xayavong MV, Slemenda SB, Wilkins PP, Silva AJ. PCR as a confirmatory technique for laboratory diagnosis of malaria. J Clin Microbiol 2006; 44:1087-1089.

17. Jojima FS, Garcia JL, Vidotto MC, Balarin MRS, Fabretti AK, Gasparini MR, et al. Occurrence and molecular characterization of Babesia species in a canine hospital population in the Londrina Region, Parana State, Brazil J Vet Parasitol 2008; 17:277-283

18. Muieed MA, Chaudhary ZI, Shakoori AR. Comparative studies on the sensitivity of polymerase chain reaction (PCR) and microscopic examination for the detection of Trypanosoma evansi in horses. Turk J Vet Anim Sci 2010; 24:507-512.

19. Azizi K, Soltani A, Alipour H. Molecular detection of Leishmania isolated from cutaneous leishmaniasis patients in Jask County, Hormozgan Province, Southern Iran, 2008. Asian Pac J Trop Med 2012; 5:514-517.

20. Shikanai-Yasuda MA, Ochs DE, Tolezano JE, Kirchhoff LV. Use of the polymerase chain reaction for detecting Trypanosoma cruzi in triatomine vectors. Trans R Soc Trop Med Hyg 1996; 90:649-651.

21. Dorn PL, Engelke D, Rodas A, Rosales R, Melgar S, Brahney B, et al. Utility of the polymerase chain reaction in detection of Trypanosoma cruzi in Guatemalan Chagas vectors. Am J Trop Med Hyg 1999; 60:740745 .

22. Edoh D, Steiger S, Genton B, Beck HP. PCR amplification of DNA from malaria parasites on fixed and stained thick and thin blood films. Trans R Soc Trop Med Hyg 1997; 91:361-363.

23. Brustoloni YM, Lima RB, Cunha RV, Dorval ME, Oshiro ET, Oliveira ALL, et al. Sensitivity and specificity of polymerase chain reaction in Giemsa stained slides for diagnosis of visceral leishmaniasis in children. Mem Inst Oswaldo Cruz 2007; 102:497-500.

24. Kirchhoff LV, Votava JR, Ochs DE, Moser DR. Comparison of PCR and microscopic methods for detecting Trypanosoma cruzi. J Clin Microbiol 1996; 34:1171-1175.

25. Paula MBC, Costa IN, Freitas PA, Limongi JE, Pajuaba Neto AA, Pinto RMC, et al. Occurrence of positivity for Trypanosoma cruzi in triatomine from municipalities in Southeastern Brazil, from 2002 to 2004. Rev Soc Bras Med Trop 2010; 43:9-14.

26. Toledo MJO, Kühl JB, Silva SV, Gasperi MV, Araújo SM. Estudo sobre triatomíneos e reservatórios silvestres de Trypanosoma cruzi no estado do Paraná, sul do Brasil. resultados preliminares. Rev Soc Bras Med Trop 1997; 30:197-203. 